\title{
Effect of Row-Spacing and Planting Density on Podding and Yield Performance of Early Soybean Cultivar 'Enrei' with Reference to Raceme Order
}

\author{
Kuniyuki Saitoh \\ Okayama University \\ Japan
}

\section{Introduction}

In Japan, the genetically modified herbicide-tolerant soybean cultivar cannot be grown in the commercial field without permission due to the public concern about the effects on the ecosystem and human health. Recently, interest for no-tilling, narrow row-spacing and dense cultivation in soybean has been increasing as a labour-saving technique. The no-tilling cultivation has an advantage in saving labor and drainage of soil, but the merit of narrow row and dense planting has not been clarified. The dense planting increases the competition among plants from the early stage and the risk of excessive growth which results in lodging. On condition that the planting density is equal, narrow row-spacing decrease the competition with plants during the earlier growth stage than wide row-spacing, and result in rapid leaf area expansion, higher crop growth rate and higher seed yield due to the development of branches, increase in the node number and pod number per node (Cooper 1977, Costa et al. 1980, Duncan 1986, Miura and Gemma 1986, Miura et al. 1987, Board et al. 1990a, 1990b, Bullock et al. 1998, Ikeda 2000). However, narrow row-spacing did not increase the yield (Beatty et al. 1982, Nakano 1989) and has been reported to even decrease the yield (Cooper and Nave 1974).

In this chapter, the factors affecting the increase in yield of narrow row and dense planting in soybean and yield determining process was clarified with reference to pod position (main stem/branches, raceme order). In order to analyze the advantages and disadvantages of narrow row and dense planting, we examined the effects of planting pattern and density on solar radiation utilization, dry-matter production and emergence of weeds.

\section{Materials and methods}

\subsection{Plant cultivation and experimental plots}

The field experiment was conducted at the Field Science Centre of Okayama University $\left(34^{\circ} 41^{\prime} \mathrm{N}, 133^{\circ} 55^{\prime} \mathrm{E}\right.$, Japan) in 2001 and 2002. The texture of the soil was sandy clay and preceding crop was pumpkin. Indeterminate soybean (Glycine max (L.) Merr.) cv. 'Enrei' (maturity group III) was used. Two seeds were sown on 13 and 14 June in 2001 and 2002, respectively, with an $80 \mathrm{~cm}$ (wide) and $30 \mathrm{~cm}$ (narrow) row-spacing, and sparse (11.1 plants 
$\mathrm{m}^{-2}, 11.25$ and $30 \mathrm{~cm}$ plant spacing in wide and narrow row-spacing, respectively) and dense (22.2 plants $\mathrm{m}^{-2}, 5.6 \mathrm{~cm}$ and $15 \mathrm{~cm}$ in wide and narrow row-spacing, respectively) planting density. Each plots size was $57.6 \mathrm{~m}^{2}(3.2 \times 18.0 \mathrm{~m})$ with no replication. A basal fertilizar was applied at the rate of $2.1 \mathrm{~g} \mathrm{~N}, 4.4 \mathrm{~g} \mathrm{P}$ and $10.0 \mathrm{~g} \mathrm{~K}$. Herbicide was applied to the soil surface to avoid weed emergence. The plants were thinned to a plant per hill when primary leaves were fully expanded. In wide row plots, soil molding was conducted by a rotary cultivator. The crop was irrigated with a water-spraying vinyl hose placed on every other row. Recommended pesticides were applied for the control of insects and diseases.

\subsection{Growth and yield observation}

Thirty plants were harvested from each plots, and ten standard plants were selected to examine the node number, main stem length, stem diameter, stem weight, and seed/stem weight ratio. Pods were distinguished on the position, main stem/branches and raceme order (Fig. 1.), and seeds were depodded manually, then weighed to record the data on yield and yield components.

The raceme orders were defined as follows (Torigoe et al. 1982). The terminal racemes appeared at the top of the stems, and first order racemes differentiate from the axil just above the petiole on the stem. The secondary racemes differentiate from both sides of the first order raceme and tertiary racemes differentiate from the sides of the secondary racemes. Racemes differentiating from both sides of the branch were classified as secondary racemes. The terminal and first order racemes, and those over secondary raceme will be collectively called basal raceme and lateral raceme, respectively. Some lateral racemes had compound leaves. The lodging score was recorded every week by measuring the angle of the main stem, and ranked 0 (erect), 1 (inclined 15 degrees), 2 (inclined 45 degrees), 3 (inclined 75 degrees) and 4 (inclined horizontally), then the average score was obtained.

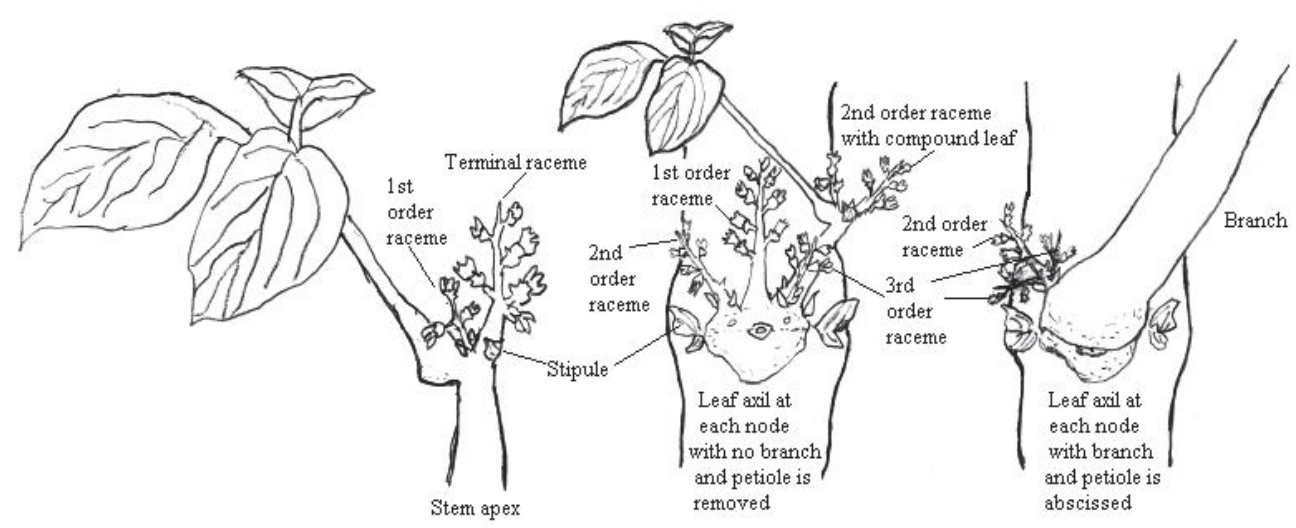

Fig. 1. Classification of raceme order in determinate type of soybean.

\subsection{Dry matter production and canopy structure}

Five plants (three replication for each plots) were sampled and three (nine plants for each plots) were separated into leaves, petioles, stems and pods on each main stem and branch, then measured the leaf area of a standard plant (AAM-8, Hayashidenko). Samples were air- 
dried at 80 degrees $C$ for 48 hours and weighed. At the beginning of flowering and full seed growth stage relative PAR (photosynthetically active radiation) at each height of the canopy were measured with a long PAR sensor (LI-191S, LI-COR) in the evening under diffuse light condition. Then, canopy structures were surveyed by the stratified clip method (Monsi und Saeki 1953). From the logarithmic relationships between cumulative LAI of the canopy top and relative PAR, the canopy light extinction coefficient $(k)$ was obtained. In addition, the relative PAR at the height of 0,60 and $120 \mathrm{~cm}$ above the ground was measured every 2.5 hours from 7 a.m. to 17 p.m., and diurnal change in light extinction coefficient under direct light condition was obtained.

\subsection{Cumulative solar radiation within canopy}

Integrated solarimeter films (R-2D, Taisei E\&L) were used for the measurement of cumulative solar radiation. Film was cut in $1 \mathrm{~cm}$ width and $2 \mathrm{~cm}$ length, then placed at $10 \mathrm{~cm}$ intervals on the square bars, $1 \mathrm{~cm}$ width and $100 \mathrm{~cm}$ length, which were installed horizontally every $15 \mathrm{~cm}$ height from the soil surface. The dye percentages were measured every six hours by a spectro-photometer (UV-1200, Shimadzu). The dye percentages had been calibrated with the cumulated solar radiation measured by radiation sensor (LI200SA, LI-COR). Accordingly, the distribution of solar radiation within a canopy was calculated.

\subsection{Weed emergence}

Three quadrats $\left(80 \mathrm{~cm}^{*} 60 \mathrm{~cm}\right)$ were randomly arranged within each plots. At the beginning of flowering stage, all weeds were sampled and the number and dry-weight of each weed species were recorded.

\section{Results}

\subsection{Growth characters}

In 2001, the precipitation was $14 \%$ lower, the average mean temperature was 0.8 degree higher, and the sunshine hours was $13 \%$ longer than the normal year, and it was characterized by low rainfall, high temperature and much sunshine. In 2002, the precipitation was $56 \%$ lower, the average mean temperature was 0.9 degree higher, and the sunshine hours was 7\% longer than the normal year, and it was characterized by drought, high temperature and much sunshine though lower than in 2001. The field was hit by a typhoon on Aug. 21 in 2001. There was no typhoon damage in 2002.

In both years, the number (per square meter) of nodes on the main stem, racemes with compound leaves and in total was higher, but in the number of branches was lower than in sparse plots (Table 1). The node number on the branches and in total was larger in wide plots than in narrow plots except that in sparse plots in 2001, and also that of racemes with compound leaf in 2001. The main stem length in dense plots was $2-12 \mathrm{~cm}$ longer than in sparse plots, and that in narrow plots was $7-16 \mathrm{~cm}$ shorter than in wide plots. The weight, diameter and section area of stem were larger than in sparse and narrow plots than dense and wide plots, respectively. The seed/stem weight ratio in dense plots was smaller than in sparse plots among the narrow plots, but not among the wide plots. The ratio in narrow plots was larger than in wide plots among the sparse plots, but not among the dense plots. 


\begin{tabular}{|c|c|c|c|c|c|c|c|c|c|c|}
\hline \multirow[b]{2}{*}{ Year / Plot } & \multicolumn{3}{|c|}{ Node number } & $\left(\mathrm{m}^{-2}\right)$ & \multirow{2}{*}{$\begin{array}{l}\text { Main } \\
\text { stem } \\
\text { length } \\
(\mathrm{cm})\end{array}$} & \multirow{2}{*}{$\begin{array}{l}\text { Stem } \\
\text { weight } \\
\text { (g) }\end{array}$} & \multirow{2}{*}{$\begin{array}{c}\text { Bran- } \\
\text { ch } \\
\text { no. } \\
\left(\mathrm{m}^{-2}\right)\end{array}$} & \multirow{2}{*}{$\begin{array}{l}\text { Stem } \\
\text { dia- } \\
\text { meter } \\
(\mathrm{mm})\end{array}$} & \multirow{2}{*}{$\begin{array}{c}\text { Stem } \\
\text { section } \\
\text { area } \\
\left(\mathrm{mm}^{2}\right) \\
\end{array}$} & \multirow{2}{*}{$\begin{array}{l}\text { Seed / } \\
\text { stem } \\
\text { weight } \\
\text { ratio } \\
\end{array}$} \\
\hline & $\begin{array}{l}\text { Main } \\
\text { stem }\end{array}$ & $\begin{array}{l}\text { Bran } \\
\text { - ch }\end{array}$ & $\begin{array}{l}\text { Rac. } \\
\text { with } \\
\text { leaf }\end{array}$ & Total & & & & & & \\
\hline 2001 & & & & & & & & & & \\
\hline Wide/Sparse & 150 & 316 & 137 & 602 & 63.4 & 18.3 & 66 & 9.4 & 53.0 & 2.20 \\
\hline Wide/ Dense & 290 & 192 & 183 & 665 & 69.6 & 8.7 & 74 & 6.9 & 30.4 & 2.51 \\
\hline Narrow/Sparse & 141 & 239 & 211 & 591 & 47.4 & 18.1 & 60 & 9.2 & 56.4 & 2.58 \\
\hline Narrow/Dense & 296 & 342 & 307 & 944 & 55.7 & 12.2 & 102 & 7.8 & 37.1 & 2.49 \\
\hline $\operatorname{LSD}_{(0.05)}$ & 9 & ns & 33 & 54 & 3.3 & 1.4 & 9 & 0.4 & 4.4 & ns \\
\hline 2002 & & & & & & & & & & \\
\hline Wide/Sparse & 159 & 272 & 71 & 502 & 61.2 & 12.5 & 60 & 8.5 & 43.5 & 1.98 \\
\hline Wide/ Dense & 301 & 248 & 121 & 670 & 63.5 & 7.7 & 89 & 7.0 & 27.8 & 2.06 \\
\hline Narrow/Sparse & 162 & 324 & 89 & 576 & 53.6 & 13.6 & 70 & 9.1 & 49.4 & 3.39 \\
\hline Narrow/Dense & 318 & 347 & 122 & 787 & 65.3 & 10.2 & 111 & 7.8 & 38.2 & 2.25 \\
\hline $\operatorname{LSD}_{(0.05)}$ & 7 & 53 & 24 & 67 & 2.5 & 1.3 & 14 & 0.1 & 3.4 & 0.50 \\
\hline
\end{tabular}

Values are means of twelve plants. 'ns' means no siginificant difference at $5 \%$ level.

Table 1. Growth characteristics (2001, 2002).

\subsection{Seed yield and yield components}

In both years, seed yields in dense plots and narrow plots were larger than sparse plots and wide plots, respectively, and those in 2001 were higher than in 2002 because of the much sunshine hours (Fig. 2, Table 2). The highest yield, $668 \mathrm{~g} \mathrm{~m}^{-2}$, was obtained in narrow/dense plots in 2001. A close correlation $(r=0.934, \mathrm{P}<0.01)$ was observed between seed yield and pod

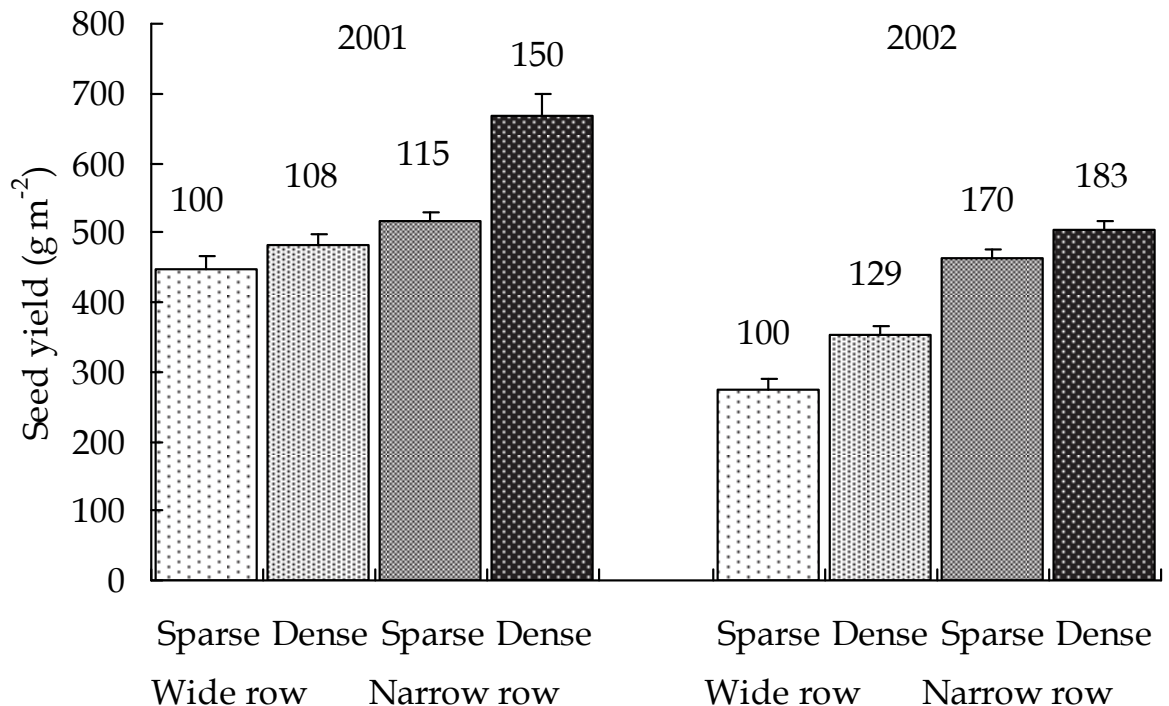

Fig. 2. Effects of planting pattern on seed yield of soybean. 
number, indicating that seed yield was determined by the pod number. Seed number per pod and seed setting ratio were not significantly different among plots, and 100 seeds weight in narrow plots tended to be slightly heavier than in wide plots, but the difference was not significant.

The pod number on the main stem relative to the total was higher in dense plots than in sparse plots, and that on the branches was higher in narrow plots than in wide plots (Table 3). The percentage share of basal raceme was higher in 2002 than in 2001. The percentage share of racemes with compound leaves was higher in dense plots than in sparse plots, and was also higher in narrow plots than in wide plots, especially in 2001.

\begin{tabular}{|c|c|c|c|c|c|}
\hline Year / plot & $\begin{array}{c}\text { Seed } \\
\text { yield } \\
\left(\mathrm{g} \mathrm{m}^{-4}\right) \\
\end{array}$ & $\begin{array}{c}\text { Pod } \\
\text { number } \\
\left(\mathrm{m}^{-\llcorner}\right)\end{array}$ & $\begin{array}{c}\text { Seed } \\
\text { number } \\
\text { per pod }\end{array}$ & $\begin{array}{c}100 \text { seeds } \\
\text { weight } \\
(\mathrm{g})\end{array}$ & $\begin{array}{c}\text { Seed } \\
\text { setting } \\
\text { ratio (\%) }\end{array}$ \\
\hline \multicolumn{6}{|l|}{2001} \\
\hline Wide/Sparse & 446 & 894 & 2.03 & 30.2 & 95.0 \\
\hline Wide/ Dense & 483 & 904 & 1.99 & 31.1 & 96.5 \\
\hline Narrow/Sparse & 515 & 1011 & 1.96 & 32.3 & 95.5 \\
\hline Narrow/Dense & 668 & 1256 & 1.99 & 31.5 & 97.4 \\
\hline $\operatorname{LSD}_{(0.05)}$ & 45 & 84 & ns & ns & ns \\
\hline \multicolumn{6}{|l|}{2002} \\
\hline Wide/Sparse & 274 & 766 & 2.04 & 26.5 & 83.7 \\
\hline Wide/ Dense & 354 & 893 & 2.01 & 27.5 & 91.3 \\
\hline Narrow/Sparse & 464 & 910 & 2.02 & 33.6 & 87.5 \\
\hline Narrow/Dense & 503 & 993 & 2.04 & 31.8 & 92.2 \\
\hline $\mathrm{LSD}_{(0.05)}$ & 26 & 83 & ns & ns & 4.5 \\
\hline
\end{tabular}

Values are means of twelve plants.

'ns' means no siginificant difference at $5 \%$ level.

Table 2. Seed yield and yield components $(2001,2002)$.

\begin{tabular}{|c|c|c|c|c|c|c|}
\hline Year / plot & $\begin{array}{l}\text { Main } \\
\text { stem }\end{array}$ & Branch & $\begin{array}{c}\text { Basal } \\
\text { raceme }\end{array}$ & $\begin{array}{l}\text { Raceme } \\
\text { with leaf }\end{array}$ & $\begin{array}{l}\text { Upper } \\
\text { raceme }\end{array}$ & Total \\
\hline \multicolumn{7}{|l|}{2001} \\
\hline Wide/Sparse & 377 (42) & $518(58)$ & 367 (41) & $262(29)$ & $266(30)$ & 894 (100) \\
\hline Wide/ Dense & $685(76)$ & $219(24)$ & $359(40)$ & $321(36)$ & $223(24)$ & 904 (100) \\
\hline Narrow/Sparse & $384(38)$ & $627(62)$ & $333(33)$ & 416 (41) & $262(22)$ & 1011 (100) \\
\hline Narrow/Dense & 702 (56) & $553(44)$ & $456(36)$ & $524(42)$ & $276(22)$ & $1256(100)$ \\
\hline $\operatorname{LSD}_{(0.05)}$ & 61 & 93 & ns & 66 & ns & 85 \\
\hline \multicolumn{7}{|l|}{2002} \\
\hline Wide/Sparse & $337(44)$ & $429(56)$ & $446(58)$ & 119 (16) & $201(26)$ & 766 (100) \\
\hline Wide/ Dense & $567(63)$ & $326(37)$ & $464(52)$ & $205(23)$ & $223(25)$ & 893 (100) \\
\hline Narrow/Sparse & $292(32)$ & $618(68)$ & $480(53)$ & 154 (17) & $276(30)$ & 910 (100) \\
\hline Narrow/Dense & 607 (61) & 387 (39) & $536(54)$ & $244(25)$ & $213(21)$ & 993 (100) \\
\hline $\operatorname{LSD}_{(0.05)}$ & 48 & 72 & ns & 43 & ns & 83 \\
\hline
\end{tabular}

Values are means of twelve plants. 'ns' means no siginificant difference at $5 \%$ level.

Values in parentheses are relative to total (100).

Table 3. Pod number on main stem or branch and raceme order $(2001,2002)$. 


\subsection{Dry weight and leaf area index}

At each growth stage, the dry-weight tended to be heavier in dense plots than in sparse plots, but the difference was not significant (Fig. 3). The dry-weight tended to be heavier in narrow plots than in wide plots except that in sparse plots at 44 days after sowing (DAS) and in dense plots at 65 DAS. At 107 DAS, the dry-weight was heaviest in narrow/dense plots and became lighter in the order of wide/dense plots > narrow/sparse plots > wide/sparse plots.

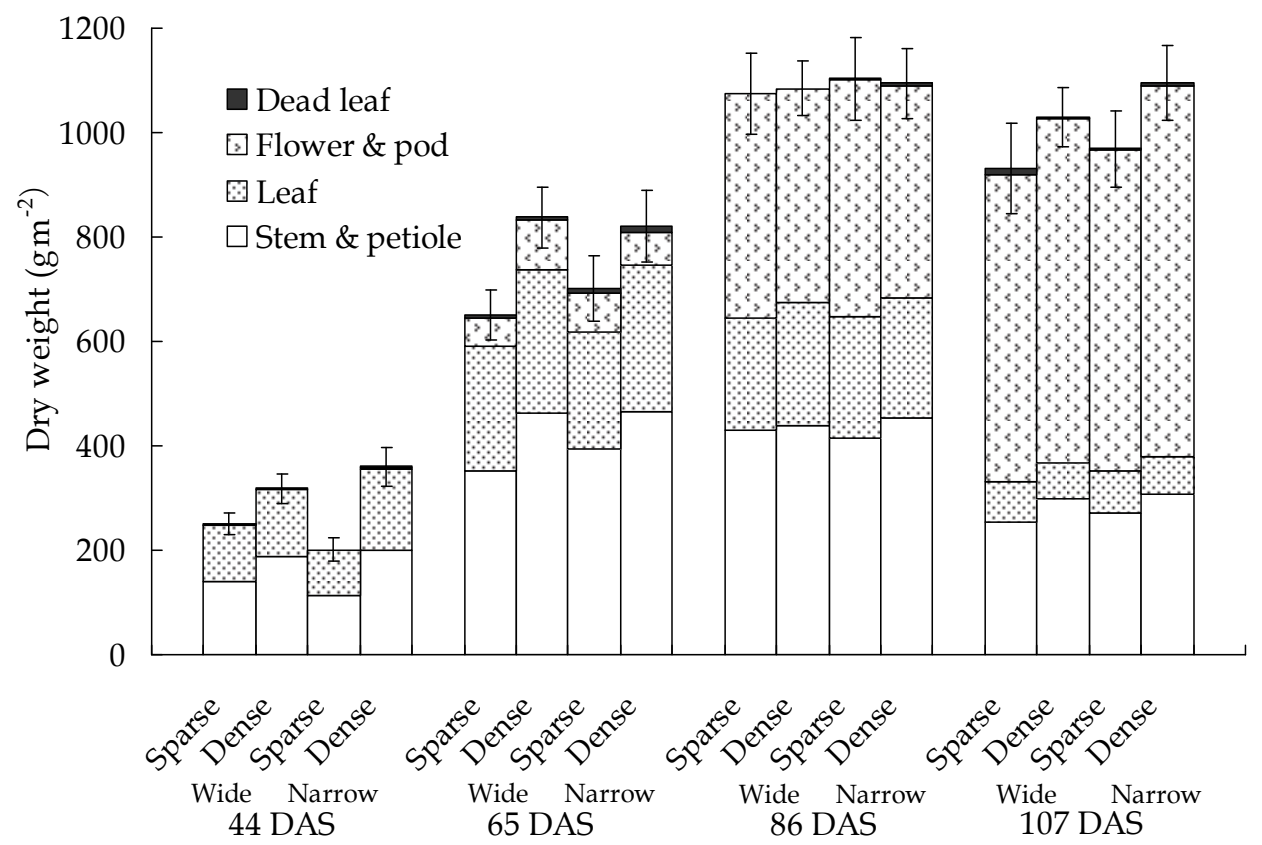

Fig. 3. Changes in cumulative dry-weight of different plant parts during growth (2001).

The leaf area index (LAI) tended to be larger in dense plots than in sparse plots, and in narrow plots than in wide plots especially at 65 DAS, when LAI in dense plots exceeded 8 (Fig. 4).

\subsection{Canopy structure}

At the flowering stage, the higher the canopy layer, the larger the leaf area from 20 to $100 \mathrm{~cm}$ above the ground in wide/dense plots, and the larger leaf area was distributed at a $40-100 \mathrm{~cm}$ height in narrow/sparse plots (Fig. 5). In dense plots, leaf area was concentrated in the 80-100 $\mathrm{cm}$ layer above the ground especially in narrow plots. The total dry-weight of non-assimilative organ was heavier in narrow plots than in wide plots. The light extinction coefficients (k), the lower value indicates that the canopy has a good light-intercepting characteristic, was in the order of narrow/dense $(0.60)<$ wide/dense $(0.68)<$ narrow/sparse $(0.73)<$ wide/sparse (0.81). It was clear that the light penetrated into a deeper layer of the canopy when planted dense and narrow row-spacing. The order of $\mathrm{k}$ at the seed growth stage coincided with that at the flowering stage (data not shown). 


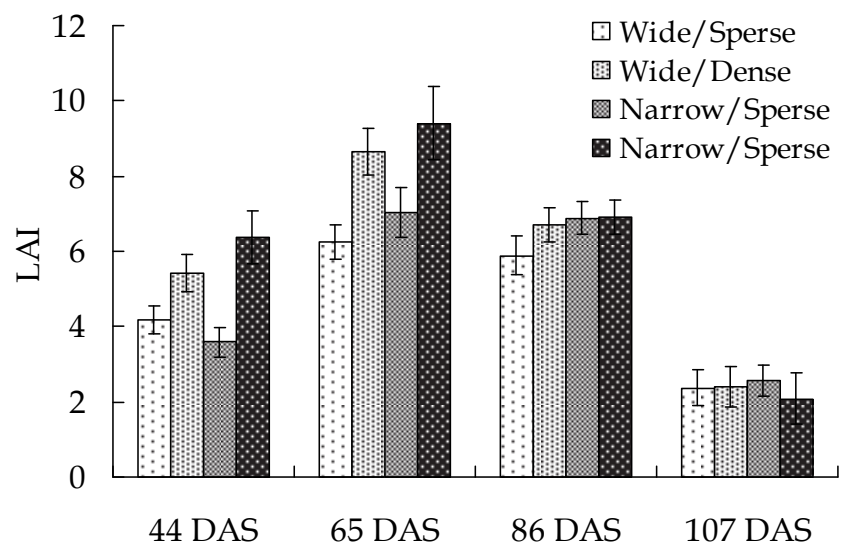

Fig. 4. Changes in LAI during growth (2001).
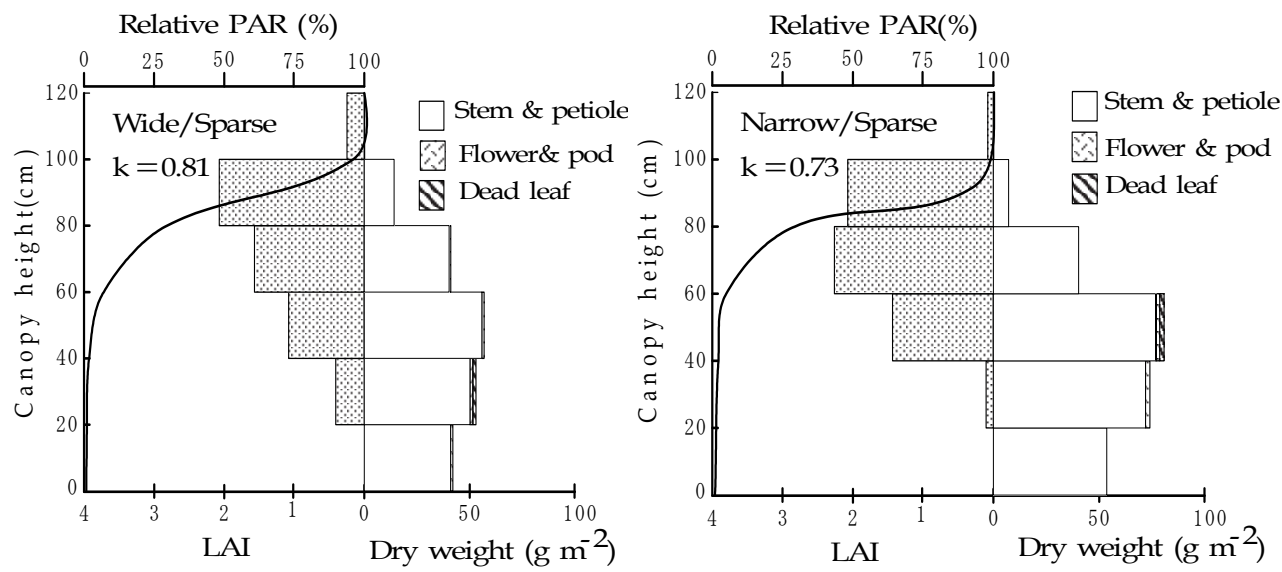

Relative PAR (\%)
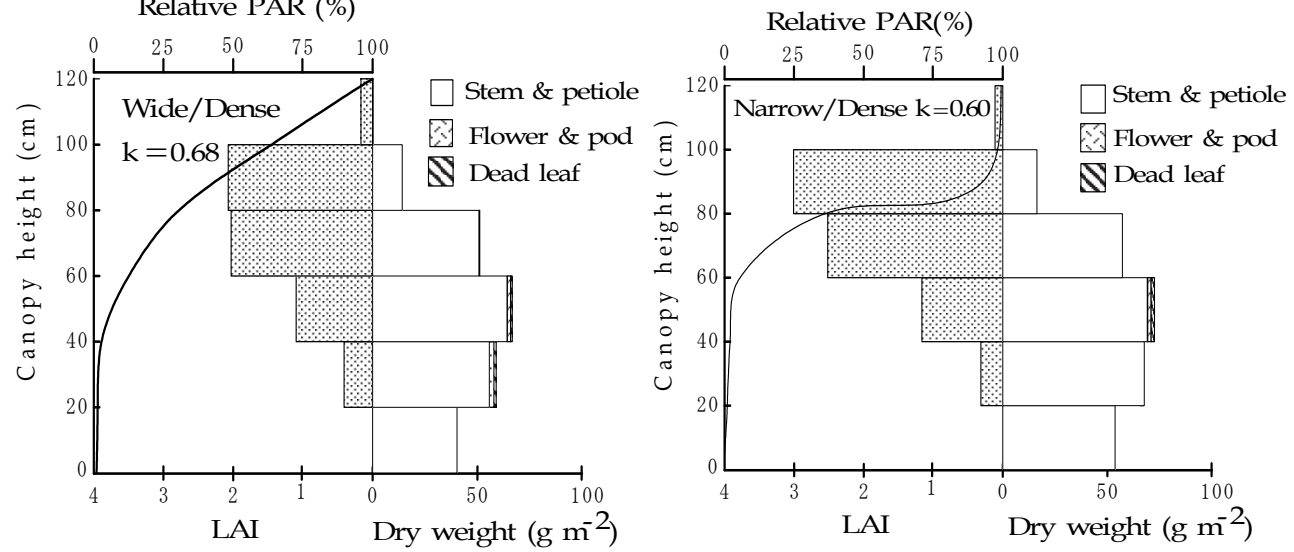

Fig. 5. Canopy structures at the full-flowering stage (2001). 


\subsection{Diurnal change in canopy light extinction coefficient (k)}

The k-value measured under direct sunlight was higher in the morning and evening, and decreased during the daytime (Fig. 6). The k-values in the morning and evening were similar to those measured under diffuse light (Fig. 5), which were lower in dense and narrow row plots. At midday, k showed the lowest value in wide plots, which suggested that the direct sunlight reached the furrow surface in the non-closed canopy in wide row plots. The extent of variation during the daytime was small in narrow plots due to the closed canopy.

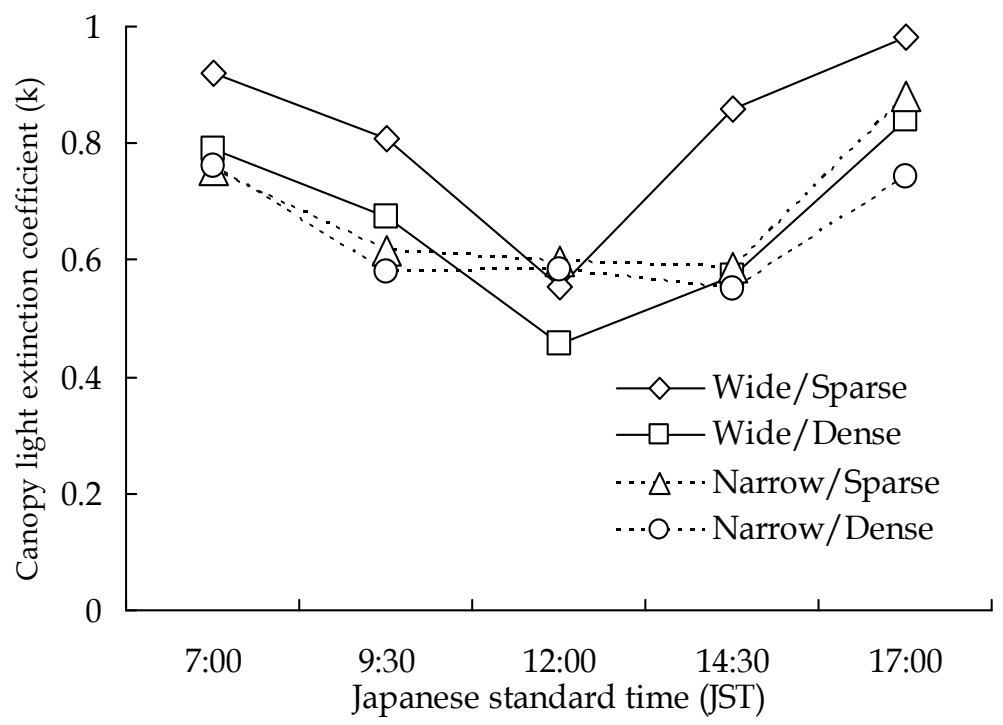

Fig. 6. Diurnal change in canopy light extinction coefficient at the beginning of the flower stage (2001).

\subsection{Distribution of cumulative solar radiation at each height within canopy}

The cumulative solar radiation at every height was lower in dense plots than in sparse plots, and was lower near the row (plant) and higher at the furrow in a direction perpendicular to the row (Fig. 7). In narrow row plots, the cumulative solar radiation was lower in dense plots than in sparse plots, and the difference between that on the row and furrow was small.

\subsection{Changes in lodging score}

In 2002, lodging did not occur in any plot. In 2001, the lodging score increased in narrow/sparse plots at 34 DAS due to a rainstorm, followed by the gradual increase in wide/sparse plots, and was larger in narrow row plots than in wide row plots (Fig. 8). At 71 DAS, when a typhoon hit, the lodging score increased markedly in dense plots, and was slightly larger in narrow/dense plots than in wide/dense plots. After lodging, plants could not recover during the later growth period. 

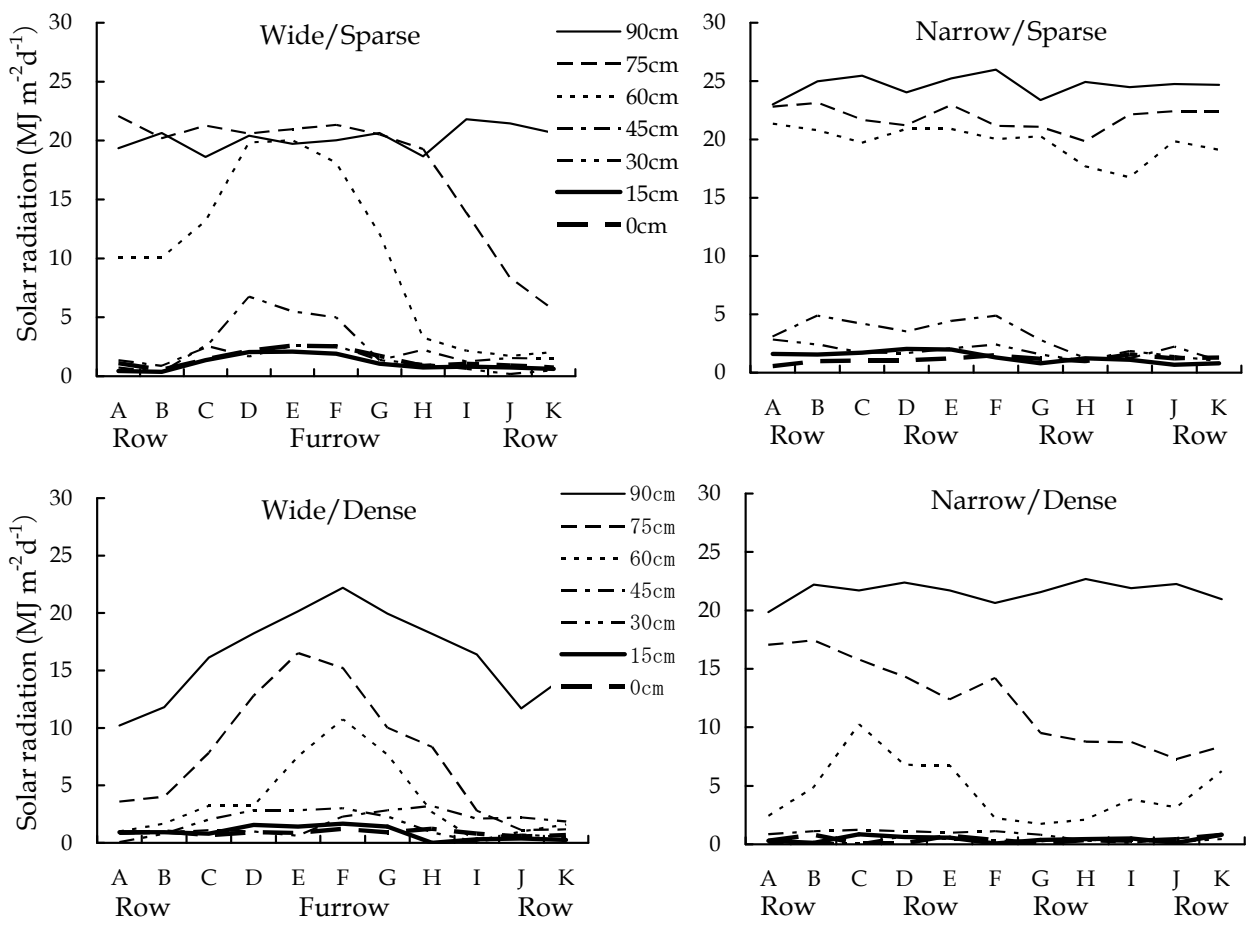

Fig. 7. Distribution of cumulative solar radiation at each height within canopy in a direction perpendicular to the row at the beginning flower stage (2001).

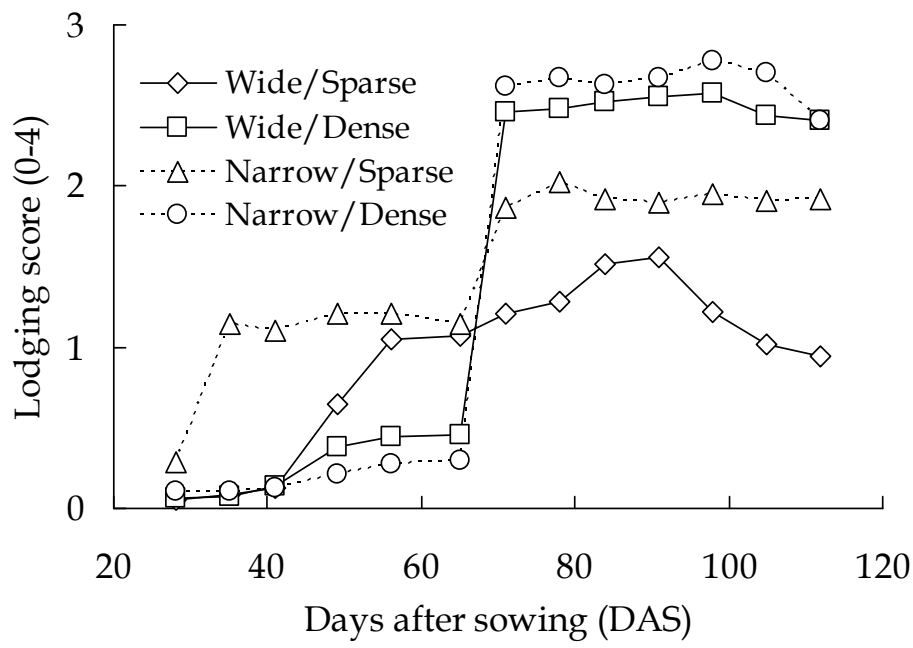

Fig. 8. Changes in lodging score (2001). 


\subsection{Weed emergence}

More weed plants appeared in 2002 than in 2001. Portulaca and Cyperus species were dominant in 2001, and Digitaria and Galinsoga in 2002. In both years, there were fewer emerged weeds in narrow plots than in wide plots.

\begin{tabular}{|c|c|c|c|c|c|c|c|c|c|c|c|}
\hline Year/Plot & $\begin{array}{c}\text { Amaranthus } \\
\text { viridis }\end{array}$ & $\begin{array}{c}\text { Portulaca } \\
\text { oleracea }\end{array}$ & $\begin{array}{c}\text { Digitaria } \\
\text { ciliaris }\end{array}$ & Cyperus & $\begin{array}{c}\text { Rorippa } \\
\text { indica }\end{array}$ & $\begin{array}{c}\text { Galinsoga } \\
\text { ciliata }\end{array}$ & $\begin{array}{c}\text { Setaria } \\
\text { viridi }\end{array}$ & $\begin{array}{c}\text { Chenopodiu } \\
\text { album }\end{array}$ & $\begin{array}{c}\text { Euphorbia } \\
\text { supina }\end{array}$ & $\begin{array}{c}\text { Mollugo } \\
\text { pentaphylla }\end{array}$ & Total \\
\hline \multicolumn{12}{|c|}{ 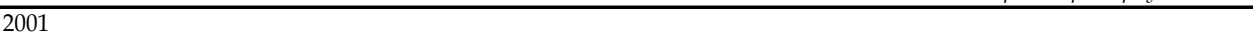 } \\
\hline Wide/Sparse & 7.6 & 9.7 & - & 8.3 & 2.1 & 2.1 & 2.1 & 2.1 & - & - & 34.0 \\
\hline Wide/ Dense & 5.2 & 16.0 & - & 7.6 & 2.1 & 2.1 & 2.1 & 9.0 & - & 3.1 & 47.2 \\
\hline Narrow/Spars€ & - & 2.1 & - & - & - & - & - & - & - & - & 2.1 \\
\hline Narrow/Dense & - & 14.6 & - & - & - & 2.1 & 2.1 & 2.1 & - & - & 20.8 \\
\hline \multicolumn{12}{|l|}{2002} \\
\hline Wide/Sparse & - & 52.8 & 11.1 & - & - & 60.2 & - & - & 28.7 & - & 124.1 \\
\hline Wide/ Dense & - & - & 23.1 & - & - & 94.4 & - & - & - & - & 117.6 \\
\hline Narrow/Spars€ & - & 63.9 & 9.3 & - & - & 11.1 & 3.7 & - & 25.0 & - & 78.7 \\
\hline Narrow/Dense & - & - & 18.5 & - & - & 45.4 & 4.6 & - & - & - & 68.5 \\
\hline
\end{tabular}

Values indicate the number of weed plants. Average of three quadrats $(80 \mathrm{~cm} * 60 \mathrm{~cm})$.

Table 4. Emergence of weeds at the beginning of flowering of soybean.

\section{Discussion}

In soybean, dense planting has been reported to increase the node number, pod number and therefore seed yield without the consideration of lodging (Nakaseko and Goto 1975, Costa et al. 1980, Miura et al. 1987, Saitoh et al. 1998a). The square- or triangular-shape planting increased the space occupied by plants than rectangular-shape planting, and promoted the development of branches, thus increasing the seed yield (Cooper 1977, Costa et al. 1980, Duncan 1986, Miura and Gemma 1986, Miura et al. 1987, Board et al. 1990b, Ikeda 2000). Nakano et al. (2001) also reported that planting pattern affected the light environment within the canopy, which determined the branch node number, pod number and seed yield. In the present study, the seed yield was in the order of narrow/dense $>$ narrow/sparse $>$ wide/dense $>$ wide/sparse (Table 2, Fig. 2), and the yield increase in narrow row planting was due to the yield increase on the branches especially on the raceme with compound leaves (Table 3).

The raceme with compound leaves is morphologically the same as a branch. The branch differentiates on the leaf axil just above the petiole on the main stem, and the raceme with compound leaves differentiates on the left and right axils of the basal raceme in the upper node of the main stem and branches, and develops a stem with one to four leaves. In a previous study, the differentiated racemes developed compound leaves when assimilates were supplied to the raceme (Saitoh et al. 2001). In the present two- year study, seed yield was positively correlated with total pod number $(\mathrm{r}=0.934, \mathrm{P}<0.001)$ and pod number on racemes with compound leaves $(\mathrm{r}=0.864, \mathrm{P}<0.01)$. Thus the increase in the pod number on the raceme with compound leaves contributed to the increase in seed yield.

The longer sunshine hours accelerated the source activity and increased assimilates were supplied to the axil of each node. Our three-year planting density experiment showed that the number of floral buds on racemes with compound leaves increased markedly in the year with longer sunshine hours (Saitoh et al. 1998a), and the pod number on racemes with compound leaves increased especially when the twelfth node was isolated by pruning the 
top above the twelfth node and removing all of the leaves, petioles and floral organs except those on the twelfth node at the flowering stage. Under such conditions, assimilates were concentrated to the twelfth node (Saitoh et al. 1998b), and the number of racemes with compound leaves on the main stem and branches increased when the leaves on branches and main stem were removed, respectively (Saitoh et al. 2001).

The present study revealed that the increase in pod number by narrow row planting was due to the increase in that on the racemes with compound leaves suggesting that the microclimate within canopy affected the development of racemes with compound leaves in narrow row-spacing. The narrow row-spacing canopy had a lower light extinction coefficient, i.e., better light-intercepting characteristics (Fig. 5).

In wide row-spacing, solar radiation was distributed non-uniformly, penetrated a deeper layer of the canopy due to fewer leaves distributed within the furrow, and decreased markedly above the row space (Fig. 7). In narrow row-spacing, solar radiation was distributed uniformly, the difference between the row and furrow was small, so that many racemes developed compound leaves due to the surplus assimilative supply to the raceme from the upper layer of canopy. The raceme with compound leaves is not only a sink organ, but also a source organ.

The canopy light extinction coefficients $(\mathrm{k})$ measured under direct sunlight decreased during the daytime (Fig. 6). The decrease in k-value means that the sunlight penetrated uniformly into a deeper layer of the closed canopy with a higher LAI, however, sunlight reached a deeper layer directly and leaves received the excess light in non-closed canopy with lower LAI like wide row-spacing. This suggests that the k-value during the daytime can not evaluate the light intercepting characteristics in non-uniformly foliage distributed canopy.

The comparison of dry matter production in the plants with different planting patterns revealed that dry-weight was heavier and LAI was larger in dense plots than in sparse plots along as shown by others (Shibles and Weber 1965, Sugiyama et al. 1967, Asanuma et al. 1977, and also in narrow row-spacing than wide row-spacing (Fig. 3, 4) in accordance with the previous studies (Bullokck et al. 1998, Duncan 1986,Shibles and Weber 1965, 1966). In narrow row-spacing, the distance between plants was longer than in wide row-spacing, so that the canopy had a better light-intercepting environment, which accelerated the development of branches and racemes with compound leaves and the expansion of leaf area during the earlier stage, though, LAI in dense planting at 65 DAS exceeded 8, which means over luxuriant growth (Sugiyama et al. 1967).

Next, we should consider the effects of lodging. The lodging score was larger in narrow plots than in wide plots, (Fig. 8). This is because the distance between plants was longer in narrow row-spacing, and there was less mutual support with the neighboring plants. After the full flowering stage, a large amount of foliage was distributed in the upper layer of the canopy in the narrow/sparse plots (Fig. 5), and the higher the center of gravity, the higher the susceptibility to lodging. In narrow row-spacing, the main stem length was $15 \mathrm{~cm}$ shorter and $0.9 \mathrm{~mm}$ thicker than in wide row-spacing in 2001 (Table 1) because the competition between plants for elongation growth decreased due to the longer distance between plants. Despite this, the lodging score was larger in narrow row-spacing, meaning that the lodging of soybean was influenced by the above ground weight and center of gravity than the main stem length and stem thickness. Further study is needed to analyze the factors affecting the lodging tolerance in soybean.

Finally, let me consider about the weed management. In narrow row-spacing, we should eradicate weeds by hand if early weed control fails. It is impossible to kill weeds by 
cultivator after sowing. It was already demonstrated that the narrow row cultivation decreased weeds emergence and the alternative application of herbicide to soil or foliage (Gramineae weeds) could control weeds with labour saving and stability (Ohdan et al. 2005). Present results also showed that the less number of weeds were appeared in narrow row plots than in wide row plots (Table 4), in both plots herbicide was applied to the soil surface after sowing and the soil molding was conducted with a rotary cultivator in wide row plots. The dry-weight of weeds per square-meter was about $2 \mathrm{~g}$, which was extremely less than that of soybean, $300-400 \mathrm{~g} \mathrm{~m}^{-2}$, i.e., weeds could be controlled sufficiently. We considered that weeds could be controlled by one application of herbicide to the soil surface after sowing. If we failed to kill weeds by the soil applied herbicide, the additional application of bentazone, newly registered foliar applied herbicide in Japan, can be used after sowing.

\section{Conclusion}

The narrow row-spacing (wide distance between plants) and dense planting in soybean increase seed yield than in the wide row-spacing (narrow distance between plants), which was caused by the decrease in competition among plants for elongation growth, the promotion of branch development, the development of racemes with compound leaves, and the increase in pod number due to the uniform light environment within the upper layer of canopy. The improvement of lodging tolerance and perfect weed control will be needed in the narrow row and dense planting of soybean were considered to be needed.

\section{References}

Asanuma, K., Naka, J. \& Kogure, K. (1977). On the relation between dry matter production and plant density in autumn type soybeans. Technical Bulletin Faculty of Agriculture Kagawa University, Vol.28, pp. 11-18, ISSN 0368-5128.

Beatty, K.D., Eldridge, I.L. \& Simpson, A.M.Jr. (1982). Soybean response to different planting patterns and dates, Agronm Journal, Vol.74, pp. 859-862, ISSN 0002-1962.

Bullokck, D., Khan, S. \& Rayburn, A. (1998) Soybean yield response to narrow rows is largely due to enhanced early growth, Crop Science, Vol.38, pp. 1011-1016, ISSN 0011-183X.

Board, J.E., Harville, B.G. \& Saxton A.M. (1990a). Narrow-row seed-yield enhancement in determinate soybean. Agronm Journal, Vol.82, pp. 64-68, ISSN 0002-1962.

Board, J.E., Harville, B.G. \& Saxton, A.M. (1990b). Branch dry weight in relation to yield increases in narrow-row soybean, Agronm Journal, Vol.82, pp. 540-544, ISSN 00021962.

Cooper, R.L. (1971). Influence of soybean production practices on lodging and seed yield in highly productive environments, Agronm Journal, Vol.63, pp. 490-493, ISSN 00021962.

Cooper, R.L. \& Nave, W.R. (1974). Effect of plant population and row width on soybean yield and harvesting loss, Transactions of the ASAE, Vol.17, pp. 801-805. ISSN 00012351

Cooper, R.L. (1977). Response of soybean cultivars to narrow rows and planting rates under weed-free conditions, Agronm Journal, Vol.69, pp. 89-92, ISSN 0002-1962. 
Costa, J.A., Oplinger, E.S. \& Pendleton, J.W. (1980). Response of soybean cultivars to planting patterns, Agronm Journal, Vol.72, pp. 153-156, ISSN 0002-1962.

Duncan, W.G. (1986). Planting patterns and soybean yield, Crop Science, Vol.26, pp. 584-588, ISSN 0011-183X.

Ikeda, T. (2000). Some factors related with net production of soybean population, Japanese Journal of Crop Science, Vol.69, pp. 12-19, ISSN 0011-1848.

Miura, H. \& Gemma, T. (1986). Effect of square planting on yield and its components of soybean under different levels of planting density, Japanese Journal of Crop Science, Vol.55, pp. 483-488, ISSN 0011-1848.

Miura, H., Wijeyathungam , K. \& Gemma T. (1987). Variation in seed yield of soybean as affected by planting patterns, Japanese Journal of Crop Science, Vol.56, pp. 652-656, ISSN 0011-1848.

Monsi, M. \& Saeki, T. (1953). Über den Lichtfactor in den Pflanzengesell schaften und seine Bedeutung für die Stoffproduktion, Japanese Journal of Botany,. Vol.14, pp. 22-52.

Nakano, H. (1989). Effect of narrow spacing on grain yield in soybean, Japanese Journal of Crop Science, Vol.58, pp. 133-134, ISSN 0011-1848.

Nakano, H., Komoto, K. \& Ishida, K. (2001). Effect of planting pattern on development and growth of the branch from each node on the main stem in soybean, Japanese Journal of Crop Science, Vol.70, pp. 40-46, ISSN 0011-1848.

Nakaseko, K. \& Goto, K. (1975). Comparative studies on dry matter production, plant type and productivity in leguminus crop. III. Dry matter production of soybean plant at various population densities, Japanese Journal of Crop Science, Vol.44 (Extra issue 2), pp. 71-72, ISSN 0011-1848.

Ohdan, H., Sumiyoshi, T. \& Koarai, A. 2005. Efficient weed control using herbicides and narrow row-dense planting for cultivation with no-intertillage of soybean cv. 'Sachiyutaka'. Report Kyushu Branch Crop Science Society of Japan, Vol.71, 30-32, ISSN 0285-3507.

Saitoh, K., Isobe, S. \& Kuroda T. (1998a). Significance of flower differentiation and development in the process of determining soybean yield : Relation between the number of pods and flowers, Japanese Journal of Crop Science, Vol.67, pp. 70-78, ISSN 0011-1848.

Saitoh, K., Isobe, S. \& Kuroda T. (1998b). Pod elongation and seed growth as influenced by nodal position on stem and raceme order in a determinate type of soybean, Japanese Journal of Crop Science, Vol.67, pp. 85-90, ISSN 0011-1848.

Saitoh, K., Isobe, S., Seguchi, Y. \& Kuroda T. (2001). Effects of source and/or sink restriction on the number of flowers, yield and dry-matter production in field-grown soybean, Japanese Journal of Crop Science, Vol.70, pp. 365-372, ISSN 0011-1848.

Shibles, R.M., \& Weber. C.R. (1965). Leaf area, solar radiation and dry matter production by soybeans, Crop Science, Vol.5, pp. 575-578, ISSN 0011-183X.

Shibles, R.M., \& Weber. C.R. (1966). Interception of solar radiation and dry matter production by various soybean planting patterns Crop Science, Vol.6, pp. 55-59, ISSN 0011-183X.

Sugiyama, S., Matsuzawa, H., Horiuch, T. \&. Kawashima, R. (1967) Effect of various planting density and pattern on growth and seed yield of soybean, Bulletin of the Nagano Agricultural Experiment Station, Vol.32, pp.34-35, ISSN 0388838X. 
Torigoe Y., Shinji H. \& Kurihara H. (1982). Studies on developmental morphology and yield determining process of soybeans. II. Developmental regularity of flower clusters and flowering habit from a view point of gross morphology, Japanese Journal of Crop Science, Vol.51, pp. 89-96, ISSN 0011-1848. 


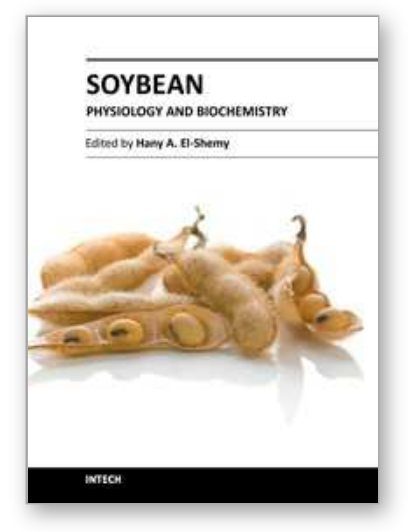

\author{
Soybean Physiology and Biochemistry \\ Edited by Prof. Hany El-Shemy
}

ISBN 978-953-307-534-1

Hard cover, 488 pages

Publisher InTech

Published online 02, November, 2011

Published in print edition November, 2011

Worldwide, soybean seed proteins represent a major source of amino acids for human and animal nutrition. Soybean seeds are an important and economical source of protein in the diet of many developed and developing countries. Soy is a complete protein and soyfoods are rich in vitamins and minerals. Soybean protein provides all the essential amino acids in the amounts needed for human health. Recent research suggests that soy may also lower risk of prostate, colon and breast cancers as well as osteoporosis and other bone health problems and alleviate hot flashes associated with menopause. This volume is expected to be useful for student, researchers and public who are interested in soybean.

\title{
How to reference
}

In order to correctly reference this scholarly work, feel free to copy and paste the following:

Kuniyuki Saitoh (2011). Effect of Row-Spacing and Planting Density on Podding and Yield Performance of Early Soybean Cultivar 'Enrei' with Reference to Raceme Order, Soybean Physiology and Biochemistry, Prof. Hany El-Shemy (Ed.), ISBN: 978-953-307-534-1, InTech, Available from:

http://www.intechopen.com/books/soybean-physiology-and-biochemistry/effect-of-row-spacing-and-plantingdensity-on-podding-and-yield-performance-of-early-soybean-cultiva

\section{INTECH}

open science | open minds

\section{InTech Europe}

University Campus STeP Ri

Slavka Krautzeka 83/A

51000 Rijeka, Croatia

Phone: +385 (51) 770447

Fax: +385 (51) 686166

www.intechopen.com

\section{InTech China}

Unit 405, Office Block, Hotel Equatorial Shanghai

No.65, Yan An Road (West), Shanghai, 200040, China

中国上海市延安西路65号上海国际贵都大饭店办公楼405单元

Phone: +86-21-62489820

Fax: $+86-21-62489821$ 
(C) 2011 The Author(s). Licensee IntechOpen. This is an open access article distributed under the terms of the Creative Commons Attribution 3.0 License, which permits unrestricted use, distribution, and reproduction in any medium, provided the original work is properly cited. 